\title{
MAKNA SIMBOLIK DAN NILAI-NILAI BUDDHIS PADA TRADISI PEMBERIAN NAMA ORANG JAWA (SUATU TINJAUAN SEMIOTIK)
}

\author{
Sudarto \\ Dosen STAB Negeri Raden Wijaya \\ dartosudarto13@gmail.com
}

\begin{abstract}
Abstrak
Penelitian ini bertujuan untuk: (1) mendeskripsikan tradisi ritual Njengakno di Desa Tunahan Kecamatan Keling Kabupaten Jepara (2)mengetahui Makna simbolik yang terkandung di dalam tradisi ritual Njengakno di Desa Tunahan Kecamatan Keling Kabupaten Jepara (3)Mendeskrepsikan Nilai-nilai Buddhis yang terkandung di dalam tradisi ritual Njengakno di Desa Tunahan Kecamatan Keling Kabupaten Jepara. Model penelitian ini menggunakan metode penelitian deskriptif kualitatif dengan menggunakan pendekatan analisis semiotik. wawancara mendalam dengan sesepuh, Tokoh Agama dan pelaku Upacara pemberian nama (Njengakno). Hasil penelitian (1) Makna simbolik yang terkandung di dalam tradisi ritual Njengakno, makna sesajian tersebut adalah: a) Jajan pasar dengan Makna rejeki, kesehatan, keselamatan supaya selalu menyertai,b) bubur putih dan bubur abang memiliki makna ditandai sebagai kelahiran seorang anak,c) Kupat lepet makna simboliknya adalah filosofi selalu mengakui kesalahan (Lepat) Sedangkan lepet menutup kesalahan yang sudah dimaafkan, d) Wedhang buthek (Kopi) dan Wedhang bening (air putih) Makna simboliknya adalah lambang sebuah persaudaraan e) Pisang memiliki Makna simbolik bahwa seluruh yang menjaga (pamomong) agar menjaga dan menopang kehidupan, f) Lilin, Makna simboliknya sebagai penerang, g) Dupa, Makna simbolik memberikan sebuah keharuman, h) Kembang (bunga) adalah nama dan keluarga sang bayi tetap harum, i) Dekem(ingkung) makna simboliknya bayi yang masih bersih dan suci sebagai sikap pasrah. (3) Nilai-nilai Buddhis yang terkandung di dalam tradisi ritual Njengakno menjelaskan bahwa Nilai-nilai Buddhis dalam tadisi upacara njengakno dapat diartikan memberikan dampak yang positif, disisi lain sebagai bentuk bakti kita kepada leluhur sesuai dengan Parrita Tirokuda sutta

Kata Kunci: Upacara Adat Njengakno, Makna Simbolik, dan Nilai-nilai Buddhis Pada Upacara Adat Njengakno
\end{abstract}

\section{PENDAHULUAN}

Indonesia merupakan negara dengan penuh keberagaman kebudayaan, suku, ras dan Agama. Keberagaman yang ada merupakan sebuah ciri yang menjadikan pembeda dengan negaranegara yang lain. Kebudayaan yang tersebar di Indonesia adalah salah satu bentuk pelestarian tradisi yang dilakukan oleh masyarakat dari peninggalan nenek moyang. Dimana tradisi tersebut dilanjutkan dan dilaksanakan secara turun temurun tanpa mengurangi makna yang ada didalam sebuah tradisi yang dilaksanakan. Tradisi atau kebudayaan disetiap masing-masing daerah

Al Qalam: Jurnal Ilmiah Keagamaan dan Kemasyarakatan Vol. 16, No. 1 Januari - Juni 2022 
Sudarto : Makna Simbolik dan Nilai-Nilai Buddhis Pada Tradisi Pemberian Nama Orang Jawa (Suatu Kajian Semiotik)

mempunyai berbagai macam makna dan tujuan. Tradisi merupakan kegiatan yang dilakukan secara turun temurun serta masing-masing daerah memiliki ragam tradisi yang berbeda-beda, selaras dengan semboyan bangasa Indonesia, berbeda-beda namun tetap satu jua. Dengan hal tersebut berbagai kebudayaan yang ada berkembang secara pesat di berbagai kalangan masyarakat secara luas.

Perkembangan zaman saat ini memberikan pengaruh yang sangat mendasar, dimana masyarakat secara berkelanjutan tidak mengetetahui serta memahami terkait tradisi yang ada, dengan hal tersebut ada harapan bahwa masyarakat nantinya dapat melestarikan secara bersamasama untuk membangun sebuah kepercayaan yang sama, sehingga dengan adanya perubahanperubahan perkembangan tidak menghalangi untuk tetap melaksanakan sebuah tradisi. Dengan adanya kesepemahaman yang sama dan mengetahui makna, tradisi tetap eksis hingga selanjutnya.

Tradisi merupakan kesepakatan masyarakat yang tetap diyakini dan dilakukan sebagai bentuk budaya kearifan yang tidak terlepas dengan adanya harapan-harapan positif serta tidak terlepas dari keberadaan agama yang bersandingan dengan hal itu, seiring dengan perkembangan kebudayaan dan tradisi tidak terlepas dengan adanya Agama yang ada di dalamnya, bahwa kedua hal tersebut saling bersandingan untuk mewujudkan sebuah makna yang terkandung didalam tradisi-tradisi yang berkembang dikalangan masyarakat. Agama dan kebudayaan saling ada keterkaitan karena agama meliputi simbol-simbol budaya sosial, Cliford Gettrtz dalam The Interpretation Of Culltures menyatakan bahwa agama meliputi simbol-simbol budaya sosial dengan hal tersebut agama dipahami sebagai sistem budaya (Hammis, 2012:235). ${ }^{1}$

Literature lain menyatakan bahwa budaya adalah sebuah sistem yang mempunyai konferensi bentuk-bentuk simbolis yang berupa, benda, sastra, lukisan, nyayian, misi, kepercayaan yang berkaitan erat dengan konsep-konsep estemologi dari sistem pengetahuan masyarakat. ${ }^{2}$ Nur Syam, 2007: 37

Kebudayaan yang ada merupakan hasil karya, rasa dan cipta masyarakat yang mampu menciptakan teknologi dan kebudayaan kebendaan yang diperlukan oleh manusia untuk menguasai alam dan sekitarnya sehingga kekuatan serta hasilnya dapat diabadikan untuk keperluan masyarakat. Masyarakat meyakini dengan adanya tradisi atau kebudayaan yang masih dilaksanakan akan membawakan berkah bagi sanak keluarga serta masyarakat yang ada secara luas.

\footnotetext{
${ }^{1}$ Hammis Syafaq. 2012. Pengantar Studi Agama. Surabaya: IAIN Sunan Ampel Press.. hlm 235

${ }^{2}$ Nur Syam. 2005. Islam pesisir,.Yogjakarta: Lkis Pelangi Aksara, hlm. 37
}

Al Qalam: Jurnal Ilmiah Keagamaan dan Kemasyarakatan Vol. 16, No. 1 Januari - Juni 2022 
Sudarto : Makna Simbolik dan Nilai-Nilai Buddhis Pada Tradisi Pemberian Nama Orang Jawa (Suatu Kajian Semiotik)

Tradisi yang melekat erat dengan kehidupan masyarakat memberikan sumber penguatan untuk tetap menjaga kelestariam kebudayaan yang ada, dengan demikian masyarakat mampu meyakini bahwa dengan adanya tradisi atau kebudayaan dilakukan tanpa adanya keterpkasaan dapat memberikan makna positif serta nilai-nilai luhur yang dapat diteladani bagi individu ataupun masyarakat. Tradisi berkembang secara merata dan secara bersama-sama untuk dilaksanakan.

Perkembangan tersebut diantaranya keberadaan tradisi yang masih dilestarikan hingga saat ini. Masyarakat Desa Tunahan melestarikan tradisi sebagai bentuk menjaga keberadaan budaya yang ada di ruanglingkup daerah serta tetap melestarikan kebudayaan secara berkelanjutan. Berbagai macam tradisi yang ada di desa Tunahan, banyak nilai-nilai yang dapat dipahami secara bersama-sama terkait masing-masing tradisi yang dilaksanakan, pada intinya disetiap tradisi yang dilaksanakan merupakan ungkapan rasa syukur, serta permohonan keselamatan kepada Tuhan Yang Maha Esa, sebagai wujud ungkapan tersebut tradisi hingga saat ini tetap dilestarikan.

Terdapat beberapa macam tradisi yang dilaksanakan oleh masyarakat Desa Tunahan diantaranya, sedekah bumi, sedekah laut, Mutoni, Njengakno dan masih bnyak tradisi yang saat ini masih diur-uri dan dilaksanakan. Melihat kondisi tersebut memberikan daya tarik tersendiri untuk mengupas secara cermat dan teliti untuk memperoleh data secara sahih dan valid untuk memberikan gambaran terkait nilai-nilai yang dapat di gali secara mendalam. Melihat kesenjangan yang ada bahwa secara luas masyarakat awam belum sepenuhnya tahu dan memahami dari makna ataupun tujuan yang ada di dalam tradisi tersebut. Dari beberapa tradisi tersebut peneliti berfokus pada satu tradisi yang diteliti, dimana tradisi tersebut bersifat umum dan selalu dilaksanakan. Sehingga nantinya dapat menjawab dan menjelaskan secara detail kepada masyarakat yang belum memahami.

Peneliti tertarik dengan adanya tradisi kebudayaan yang dilakukan oleh masyarakat desa Tunahan salah satunya tradisi tersebut adalah penamaan bayi di dalam bahasa daerah desa Tunahan disebut dengan nama Njengakno. Tradisi Njenagakno merupakan tradisi wajib yang dilaksanakan dikarenakan tradisi tersebut adalah ritual yang dilaksanakan untuk pemberian nama seorang anak yang telah lahir. Dimana tradisi penamaan bayi yang baru lahir merupakan sebuah doa ataupun harapan dari makna nama yang akan diberikan kepada anak yang baru lahir tersebut. Doa, harapan baik, kesejahteraan dan hal-hal yang dapat dijauhkan dari mara bahaya merupakan tujuan dengan adannya ritual pemberian nama tersebut.

Terdapat keunikan pada tradisiNjengaknodimana tradisi tersebut dapat dilakasanakan dengan adanya pembeda waktu pelaksanaan, maksudnya jika anak laki-laki pemberian nama

Al Qalam: Jurnal Ilmiah Keagamaan dan Kemasyarakatan Vol. 16, No. 1 Januari - Juni 2022 
Sudarto : Makna Simbolik dan Nilai-Nilai Buddhis Pada Tradisi Pemberian Nama Orang Jawa (Suatu Kajian Semiotik)

setelah satu minggu pasca lahir atau sepasar namun jika anak yang baru lahir tersebut perempuan, tradisi njengakno dilaksanakan setelah satu bulan atau selapan. Tradisi pemberian nama tersebut tentu diyakini oleh masyarakat setempat untuk dijadikan sebagai kebudayaan turun-temurun dari nenek moyang yang diyakini pemberian nama kepada putra atau putri akan membawkan berkah kebaikan, kesehatan dan kesejahteraan.

Alasan diambilnya obyek penelitian upacara tradisi dalam awal mula pemberian nama pada bayi karena berbagai bentuk serangkaian upacara tradisi yang berhubungan dengan prosesi Njengakno orang masih dilakukan oleh masyarakat kota Jepara khususnya di Kecamatan Keling Kabupaten Jepara. Salah satu bentuk upacara tradisi yang ada terdapat upacara Njengakno yang masih dipakai masyarakat Jawa dalam memberikan nama kepada bayi hingga saat ini.

Berkaitan dengan pemberian nama dalam upacara tersebut terdapat beberapa sesajian yang disediakan dalam acara njengakno, berdasarkan hal tersebut tentu ada makna-makna di dalam sesajian yang dipergunakan dalam tradisi pemberian nama, serta terdapat nilai nilai Buddhis yang terdapat dalam upacara ritual pemberian nama. Harapan berlangsungya penelitian ini dapat memberikan sebuah pengetahuan baru bagi masyarakat yang belum memahami ditinjau dari adanya nilai-nilai yang terkandung. Berdasarkan penjelasan di atas memberikan gambaran bahwa peniliti hendak melaksanakan penelitian dengan judul Makna Simbolik Dan Nilai-Nilai Buddhis Pada Tradisi Pemberian Nama Orang Jawa Di Desa Tunahan Kecamatan Keling Kabupaten Jepara (Suatu Tinjauan Semiotik)

Tujuan dalam penelitian Makna Simbolik Dan Nilai-Nilai Buddhis Pada Tradisi Pemberian Nama Orang Jawa Di Desa Tunahan Kecamatan Keling Kabupaten Jepara adalah untuk mengetahui dan mendeskripsikan tradisi ritual Njengakno di Desa Tunahan Kecamatan Keling Kabupaten Jepara, untuk mengetahui Makna simbolik yang terkandung di dalam tradisi ritual Njengakno di Desa Tunahan Kecamatan Keling Kabupaten Jepara dan mendeskrepsikan Nilai-nilai Buddhis yang terkandung di dalam tradisi ritual Njengakno di Desa Tunahan Kecamatan Keling Kabupaten Jepara.

\section{KAJIAN TEORI}

Kamus Besar Bahasa Indonesia (Poerwadarminta, 1976:624) dinyatakan bahwa makna merupakan arti atau maksud (sesuatu kata) 3. "Makna adalah konsep abstrak pengalaman manusia, tetapi bukanlah pangalaman orang perorang"4 (Dewa dan Rohmadi, 2008:11).

${ }^{3}$ Poerwadarminta, W.J.S. 1976. Kamus Umum Bahasa Indonesia. Jakarta: Balai Pustaka. Hlm 624 11

${ }^{4}$ Dewa I, P.W \& Rohmadi, M. 2008. Semantik Teori dan Anlisis. Surakarta: Yuma Pustaka., hlm

Al Qalam: Jurnal Ilmiah Keagamaan dan Kemasyarakatan Vol. 16, No. 1

Januari - Juni 2022 
Sudarto : Makna Simbolik dan Nilai-Nilai Buddhis Pada Tradisi Pemberian Nama Orang Jawa (Suatu Kajian Semiotik)

Ada 3 corak makna yaitu, (1) makna inferensial, yakni makna satu kata (lambang) adalah objek, pikiran, gagasan, konsep yang ditunjuk oleh kata tersebut. Proses pemikiran makna terjadi ketika kita menghubungkan lambang dengan ditujukan lambang; (2) makna yang menunjukkan arti (significance) suatu istilah dihubungkan dengan konsep-konsep yang lain; (3) makna infensional, yakni makna yang dimaksud oleh pemakai simbol. Jadi, makna merupakan objek, pikiran, gagasan, konsep yang dirujuk oleh suatu kata, yang yang dihubungkan dengan yang ditujukan simbol atau lambang ${ }^{5}$ ( J.Rakhmat, 1994:277).

Makna adalah konsep, gagasan, ide, atau pengertian yang berada secara padu bersama satuan kebahasaan yang menjadi penandanya, yaitu kata, frasa, dan kalimat ${ }^{6}$ (Santoso, 2006:10). Simbolik adalah perlambangan; menjadi lambang; misalnya lukisanlukisan ${ }^{7}$ (Poerwadarminta, 1976:946). Simbol merupakan bentuk lahiriyah yang mengandung maksud. Dapat dikatakan bahwa simbol adalah tanda yang meberitahukan sesuatu kepada orang lain, yang mengacu pada objek tertentu di luar tanda itu sendiri yang bersifat konvensional. "Simbol adalah tanda yang memiliki hubungan konvensional dengan yang ditandainya, dengan yang dilambangkannya,dan sebagainya" ${ }^{8}$ (Dewa dan Rohmadi, 2008:12).

Berdasarkan uraian di atas dapat ditarik kesimpulan bahwa simbol dan makna merupakan dua unsur yang berbeda, tapi saling berkaitan, bahkan saling melengkapi. Kesatuan simbol dan makna ini akan menghasilkan suatu bentuk yang mengandung maksud. Jadi, makna simbolik adalah makna yang terkandung dalam suatu hal atau keadaan yang merupakan pengantar pemahaman terhadap suatu objek.

Sistem simbol adalah suatu yang diciptakan oleh manusia dan secara konvensional digunakan bersama, teratur dan benar-benar dipelajari, sehingga memberi pengertian hakikat "manusia", yaitu suatu kerangka yang penuh dengan arti untuk mengorientasikan dirinya kepada yang lain, kepada lingkungan dan kepada dirinya sendiri, sekaligus sebagai produk dan ketergantungan dalam interaksi sosial ${ }^{9}$ (Sumandiyo, 2007:22).

Simbol dalam kehidupan manusia memegang peranan penting, karena dalam simbol manusia dapat mengungkapkan atau menyatakan gagasan, pikiran, atau maksud tertentu seseorang kepada orang lain. Sistem simbol dapat pula dipahami sebagai sistem penandaan (semiotika). Sistem penandaan pandangan semiotika ini mengandung makna harfiah, bersifat

\footnotetext{
${ }^{5}$ Jalaludin, Rakhmat. (1994). Psikologi Komunikasi. Bandung: Remaja Rosdakarya.hlm 277

${ }^{6}$ Santoso, Joko. 2006. Semantik. Yogyakarta: FBS UNY hlm 10

${ }^{7}$ Poerwadarminta, W.J.S. 1976. Kamus Umum Bahasa Indonesia. Jakarta: Balai Pustaka. Hlm 946

${ }^{8}$ Dewa I, P.W \& Rohmadi, M. 2008. Semantik Teori dan Anlisis. Surakarta: Yuma Pustaka. Hlm

${ }^{9}$ Sumandiyo.2007. Sosiologi Budaya, Yogyakarta: Pustaka hlm 22
}

Al Qalam: Jurnal Ilmiah Keagamaan dan Kemasyarakatan Vol. 16, No. 1 Januari - Juni 2022 
Sudarto : Makna Simbolik dan Nilai-Nilai Buddhis Pada Tradisi Pemberian Nama Orang Jawa (Suatu Kajian Semiotik)

primer dan langsung ditunjukkan menurut kesepakatan/konvensi yang dibentuk secara bersama oleh masyarakat atau budaya dimana simbol atau tanda itu berlaku ${ }^{10}$ (Sumandiyo, 2007:23-24).

Semiotika adalah suatu metode analisis yang digunakan untuk mengkaji suatu tanda. Seperti tanda-tanda dalam kehidupan sehari-hari. Secara etimologis, istilah semiotika berasal dari kata Yunani semeion yang berarti "tanda". Tanda itu sendiri didefinisikan sebagai sesuatu yang atas dasar konvensi sosial yang terbangun sebelumnya, dapat dianggap mewakili sesuatu yang lain.

Secara terminologis, semiotika dapat didefinisikan sebagi ilmu yang mempelajari sederetan luas objek-objek, peristiwaperistiwa, seluruh kebudayaan sebagai tanda. Van Zoest mengartikan semiotika sebagai "ilmu tanda (sign) dan segala yang berhubungan dengannya cara berfungsinya, hubungannya dengan kata lain, pengirimannya, dan penerimaannya oleh mereka yang mempergunakannya ${ }^{11}$ Alex Sobur, 2004:95-96)

Analisis semiotika dapat digunakan untuk mencari makna-makna dari teks yang berupa lambang-lambang (sign). Dengan kata lain, pemaknaan terhadap lambang-lambang dalam tekslah yang menjadi pusat perhatian analisis semiotik. ${ }^{12}$ (Pawito, 2007:155-156) Selain istilah semiotika dalam sejarah linguistik ada pula digunakan istilah lain, seperti: semiologi, semasiologi, semanik, dan semik untuk merujuk pada bidang studi yang mempelajari makna atau arti dari suatu tanda atau lambang. ${ }^{13}$ Alex Sobur, 2013:11)

Komunikasi menjadi efektif ketika tanda-tanda dipahami dengan baik berdasarkan pengalaman pengirim maupun penerima pesan. Sebuah pengalaman (perceptual field) adalah jumlah total berbagai pengalaman yang dimiliki seseorang selama hidupnya. Semakin besar kesesuaian (commonality) dengan perceptual field penerima pesan, maka semakin besar pula kemungkinan tanda-tanda dapat diatikan sesuai dengan apa yang dimaksud oleh pengirim pesan.

Tradisi adalah kebiasaan yang diwariskan dari suatu generasi kegenerasi berikutnya secara turun-temurun, mencakup berbagai nilai budaya yang meliputi adat istiadat, sistem kepercayaan, dan sebagainya, kata tradisi berasal dari bahasa Latin "tradition" yang berarti diteruskan. Dalam pengertian yang paling sederhana, tradisi diartikan sebagai sesuatu yang telah dilakukan untuk sejak lama dan menjadi bagian dari kehidupan suatu kelompok masyarakat.( ${ }^{14}$ Nur Syam, 2005:16-18)

\footnotetext{
${ }^{10}$ Sumandiyo.2007. Sosiologi Budaya, Yogyakarta: Pustaka hlm 22-24

11 Alex Sobur.2004. Analisis Teks Media. Bandung: PT Remaja Rosdakarya hlm 95-96

12 Pawito. 2007.Penelitian Komunikasi Kualitatif .Yogyakarta: PT LkiS Pelangi Aksara Yogyakarta. Hlm 155-156

13 Alex Sobur. 2013. Semiotika Komunikasi, Bandung : PT. Remaja Rosdakarya, hlm 11

${ }^{14}$ Nur Syam. 2005. Islam pesisir,. Yogjakarta: Lkis Pelangi Aksara, hlm 16-18
}

Al Qalam: Jurnal Ilmiah Keagamaan dan Kemasyarakatan Vol. 16, No. 1 Januari - Juni 2022 
Sudarto : Makna Simbolik dan Nilai-Nilai Buddhis Pada Tradisi Pemberian Nama Orang Jawa (Suatu Kajian Semiotik)

Dalam pengertian tradisi ini, hal yang paling mendasar dari tradisi adalah adanya informasi yang diteruskan dari generasi ke generasi baik tertulis maupun (sering kali) lisan oleh karena tanpa adanya ini, suatu tradisi dapat punah. Selain itu, tradisi juga dapat diartikan sebagai kebiasaan bersama dalam masyarakat manusia, yang secara otomatis akan mempengaruhi aksi dan reaksi dalam kehidupan sehari-hari para anggota masyarakat itu, bisaanya dari suatu Negara, kebudayaan, waktu, atau agama yang sama. Hal yang paling mendasar dari tradisi adalah adanya informasi yang diteruskan dari generasi ke generasi baik tertulis maupun lisan, karena tanpa adanya ini, suatu tradisi dapat punah. ${ }^{15}$ (Kuncoroningrat, 1964: 19)

Muhaimin, (2011:11), mengungkapkan bahwa Tradisi merupakan sebuah persoalan dan yang lebih penting lagi adalah bagaimana tradisi tersebut terbentuk. Menurut Funk dan Wagnalls seperti yang dikutip oleh Muhaimin tentang istilah tradisi di maknai sebagai pengatahuan, doktrin, kebisaaan, praktek dan lain-lain yang dipahami sebagai pengatahuan yang telah diwariskan secara turun-temurun termasuk cara penyampaian doktrin dan praktek tersebut ${ }^{16}$.

Berdasarkan pengertian di atas dapat disimpulkan bahwa tradisi adalah sebuah kepercayaan bagi masyarakat secara luas yang dilakukan secara turun menurun dan membudaya, yang di dalamnya akan mempengaruhi aksi dan reaksi bagi pelaku tradisi tersebut.

\section{METODE PENELITIAN}

Jenis penelitian ini adalah penelitian kualitatif deskriptif, yaitu data yang dikumpulkan berbentuk kata-kata, gambar, bukan angka-angka. ${ }^{17}$ Sudarwan (2002: 2). Menurut Bogdan dan Taylor, sebagaimana yang dikutip oleh Lexy J. Moleong, penelitian kualitatif adalah prosedur penelitian yang menghasilkan data deskriptif berupa kata-kata tertulis atau lisan dari orang-orang dan perilaku yang diamati. ${ }^{18}(2000: 3)$.

Sementara itu, penelitian deskriptif adalah suatu bentuk penelitian yang ditujukan untuk mendeskripsikan atau menggambarkan fenomena-fenomena yang ada, baik fenomena alamiah maupun rekayasa manusia ${ }^{19}$ (Moleong 2000: 3).

\footnotetext{
${ }^{15}$ Kuncoroningrat. 1954. Sejarah Kebudayaan Indonesia. Yogyakarta: Jambatan, hlm19

${ }^{16}$ Muhaimin AG.2001. Islam Dalam Bingkai Budaya Lokal: Potret Dari Cerebon, Terj. Suganda, Ciputat: Logos Wacana Ilmu, hlm 11

${ }^{17}$ Sudarwan Danim. 2002. Menjadi Peneliti Kualitatif Rancangan Metodologi, Presentasi, dan Publikasi Hasil Penelitian untuk Mahasiswa dan Penelitian Pemula Bidang Ilmu Sosial, Pendidikan, dan Humaniora. Bandung: Remaja Rosdakarya, hlm 2

${ }^{18}$ Lexy. J. Moleong. 2000. Metodologi Penelitian Kualitatif. Bandung: PT Remaja Rosdakarya, $\operatorname{hlm} 3$

${ }^{19}$ Lexy. J. Moleong. 2000. Metodologi Penelitian Kualitatif. Bandung: PT Remaja Rosdakarya, hlm 3
}

Al Qalam: Jurnal Ilmiah Keagamaan dan Kemasyarakatan Vol. 16, No. 1 Januari - Juni 2022 
Sudarto : Makna Simbolik dan Nilai-Nilai Buddhis Pada Tradisi Pemberian Nama Orang Jawa (Suatu Kajian Semiotik)

Penelitian ini menggunakan pendekatan pengakajian analisis semiotika berkenaan dengan Simbol atau makna simbolik dar Charles Sander Peirce. Adapun tujuan dari penelitian deskriptif adalah untuk membuat pencandraan secara sistematis, faktual, dan akurat mengenai fakta dan sifat populasi atau daerah tertentu. Penelitian ini digunakan untuk mengetahui Makna Simbolik dan Nilai-Nilai Buddhis dalam Tradisi pemberian nama di desa Tunahan Kabupaten Jepara

Analisis data yang digunakan adalah metode deskriptif analitik, yaitu mendeskripsikan data yang dikumpulkan berupa kata-kata, gambar, dan bukan angka. Data yang berasal dari naskah, wawancara, catatan lapangan, dokuman, dan sebagainya, kemudian dideskripsikan sehingga dapat memberikan kejelasan terhadap kenyataan atau realitas ${ }^{20}$ (Sudarto, 1997: 66).

Analisis data versi Miles dan Huberman, bahwa ada tiga alur kegiatan, yaitu reduksi data, penyajian data, serta penarikan kesimpulan atau verifikasi ${ }^{21}$ (Husaini Usman, 2009: 85-89). Reduksi data diartikan sebagai proses pemilihan, pemusatan perhatian pada penyederhanaan, pengabstrakan, dan transformasi data "kasar" yang muncul dari catatan lapangan. Reduksi dilakukan sejak pengumpulan data, dimulai dengan membuat ringkasan, mengkode, menelusuri tema, menulis memo, dan lain sebagainya, dengan maksud menyisihkan data atau informasi yang tidak relevan, kemudian data tersebut diverifikasi. Penyajian data adalah pendeskripsian sekumpulan informasi tersusun yang memberikan kemungkinan adanya penarikan kesimpulan dan pengambilan tindakan. Penyajian data kualitatif disajikan dalam bentuk teks naratif, dengan tujuan dirancang guna menggabungkan informasi yang tersusun dalam bentuk yang padu dan mudah dipahami. Penarikan kesimpulan atau verifikasi merupakan kegiatan akhir penelitian kualitatif. Peneliti harus sampai pada kesimpulan dan melakukan verifikasi, baik dari segi makna maupun kebenaran kesimpulan yang disepakati oleh tempat penelitian itu dilaksanakan.

\section{HASIL DAN PEMBAHASAN}

\section{Tradisi Ritual Njegakno(Pemberian Nama) Di Desa Tunahan}

Tradisi yang terdapat di masyarakat Desa Tunahan merupakan tradisi yang bersifat turun temurun yang diwariskan oleh nenek moyang. Tradisi atau upacara adat yang ada sangat banyak yang dilakukan oleh anggota masyarakat, salah satunya adalah tradisi pemberian nama kepada anak yang baru lahir. Tradisi tersebut dinamakan njengakno oleh masyarakat Desa Tunahan Kecamatan Keling Kabupaten Jepara.

\footnotetext{
${ }^{20}$ Sudarto. 1997. Metodologi Penelitian Filsafat. Jakarta: Raja Grafindo Persada, hlm 66

${ }^{21}$ Husaini Usman dan Purnomo Setiadi Akbar. 2009. Metodologi Penelitian Sosial. Jakarta: PT Bumi Aksara, hlm 85-89
}

Al Qalam: Jurnal Ilmiah Keagamaan dan Kemasyarakatan Vol. 16, No. 1 Januari - Juni 2022 
Sudarto : Makna Simbolik dan Nilai-Nilai Buddhis Pada Tradisi Pemberian Nama Orang Jawa (Suatu Kajian Semiotik)

Upacara njengakno merupakan suatu tradisi atau ritual yang bersifat sakral dan sangat berarti bagi masyarakat. Pada upacara tradisi tersebut terdapat unsur yang menyangganya. Dengan adanya unsur penyangga tersebut tradisi pemberian nama orang tidak akan pernah terlaksana dengan sempurna. Unsur-unsur tersebut diantaranya, a) unsur rangkaian acara ritual njengakno, b) unsur berdasarkan waktu dalam penyelenggaraan upacara ritual njengakno, c) unsur pelaku dalam acara ritual njengakno, d) unsur perlengkapan dalam upacara ritual njengakno, dan e) unsur doa dalam upacara tradisi njengakno.

1. Unsur pada Upacara Ritual Njengakno di Desa Tunahan Kecamatan Keling Kabupaten Jepara

Rangkaian upacara adat njengakno di Desa Tunahan seperti yang diungkapan oleh bapak Kariyan (65), orang yang dituakan oleh masyarakat desa Tunahan (Sesepuh desa), menjelaskan bahwa penyelenggaraan upacara njengakno merupakan sebuah rangkaian upacara ritual yang memberikan makna serta tujuan untuk berkah keselamatan bagi sang bayi yang baru lahir. Disisi lain maksud dari pelaksanaan ritual njengakno tersebut merupakan sebuah tradisi yang diuri-uri oleh masyarakat desa Tunahan sebgai bentuk tradisi turun-temurun. Dengan memiliki keyakinan bahwa dengan diadakanya ritual tersebut dapat memberikan sebuah kebermanfaatan bagi sang bayi yang baru lahir, kebermanfaatan tersebut adalah bertujuan untuk memebrikan keselamatan dan terbebas dari malapetaka yang ditimbulkan oleh berbagai macam roh halus, arwah leluhur dan lain sebagainya. Malapetaka tersebut dapat terhindar apabila keluarga senantiasa melaksanakan ritual-ritual yang ditujukan kepada leluhur dan makhluk halus. Apabila hal tersebut tidak dilaksanakan merupakan sebuah pantangan yang nantinya sang anak menjadi rewel (menangis terus menerus di waktu sore (surup) (Desa Tunahan, wawancara dengan bapal Kariyan, 24 April 2021).

Ritual pemberian nama atau njengakno merupakan salah satu bentuk pelaksana etika sosial. Etika sosial tersebut memeberikan pengaruh untuk tetap melestarikan adat kebudayaan yang dilaksanakan secara turun temurun dalam hhal pelaksanaan ritual njengakno. Mengabaikan pelaksanaan adat tersebut memperlihatkan rasa peduli terhadap kegiatan ritual yang diwariskan oleh nenek moyang dan tidak menunjukan sebuah solidaritas tinggi terhadap adat istiadat dan mengakibatkan nama buruk atau celaan bagi keluarga yang bersangkutan dikelompok sosial. Dikarenakan ritual tersebut merupakan sebuah siklus hidup dimana seseorang harus melaluinya sebagai bentuk rasa syukur serta menghormati leluhur, apabila ritual tersebut tidak dilaksanakan maka kelak hidupnya akan tidak tentram. Dalam kehidupanya mendapatkan berbagau gejolak atau banyak masalah yang dihadapi hal tersebut merupakkan kepercayaan yang bersifat turun-temurun dari nenek moyang yang tidak bisa ditinggalkan dan sudah melekat dalam diri orang jawa.

Al Qalam: Jurnal Ilmiah Keagamaan dan Kemasyarakatan Vol. 16, No. 1 Januari - Juni 2022 
Sudarto : Makna Simbolik dan Nilai-Nilai Buddhis Pada Tradisi Pemberian Nama Orang Jawa (Suatu Kajian Semiotik)

Pelaksanaan rangkaian upacara tradisi njengakno dari awal kelahiran samapai dengan pemberian namasecara menyeluruh akan dijelaskan oleh Bapak Kariyan selaku sesepuh desa setempat. Menurut beliau setelah kelihiran sang bayi, ari-ari (batir bayi) akan di dibersihkan dan dicuci oleh dukun bayi selanjutnya dimasukan didalam kendil atau periuk dan dibacakan doa sebelum dan sesudah dimasukkan atau di tanam di samping pintu masuk rumah kemudian dipagari dan diberi lampu teplok (lampu dari minyak). Pagar yang dimaksudkan adalah untuk melindungi ari-ari dari makhluk atau hewan yang akan memekan sedangkan lampu tersebut berfungsi sebagai penerangan atau pencahayaan. Hal tersebut dilaksanakan untuk meberikan maksud bahwa ari-ari yang sudah ditanam di depan pintu dapat menjaga sang bayi dari godaan yang muncul dari luar, makhluk halus atau sawan. Ari-ari yang sudah ditanam tersebut merupakan sesuatu yang dihormati selayaknya orang meninggal.

Ari-ari yang ditanam harus dengan menggunakan kedua tangan sebab jika menggunakan tangan satu saja atau menggunakan tangan kiri dipercayaai bahwa nanti sang bayi akan kidal, serta dalam penanaman ari-ari harus ditempatkan di dekat pintu masuk dan tidak ditempat yang basah. Setelah empat sampai lima hari setelah kelahiran sang bayi biasany tali pusar sudah terputus dalam bahasa jawanya adalah puputan putus tali pusar. Dengan berlangsungnya puput tali pusar tersebut keluarga melaksanakan upacara adat yang disebut sebagai Puputan untuk menandai lepasnya tali pusar sang bayi.

Upacara dilaksanakan pada waktu sore hari yang dihadiri oleh masyarakat sekitar atau tetangga dan kerabat dekat. Namun apabila daam waktu 4-5 hari tersebut belum uput pusar maka jagong bayen tetap berlangsung. Jagong bayen merupakan bagian dari rangkain upacara tersebut dalam artian jagong bayen merupakan kegiatan yang dilaksanakan oleh tetangga atau kerabat yang datang setiap malam untuk melekan. Melekan biasa dilakukan oleh bapak-bapakyang dilaksanakan di tempat orang yang baru melahirkan dan biasanya jagong bayen tersebut melaksanakan kegiatan seperti main kartu, cerita ataupun kegiatan lainya. Hal ini bertujuan untuk menjaga sang bayi yang belum puput pusar dan ibunya agar tidak di ganggu oleh roh-roh jahat. Dikarenakan sebelum sang bayi puput pusar biasaanya rawan terganggu oleh makhluk-mahkluk halus.

Setelah puput pusar, potongan pusar disimpan dan di tanam di dekat aruman (dikubur bersama ari-ari), semua dilakukan dengan diiringi doa keselamatan bagi sang bayi. Setelah ritual tersebut dilaksanakan selanjutnya diadakan upacara sepasaran atau Njengakno (peberian nama) kepada sang bayi.

Upacara Njengakno dilaksanakan setelah puput pusar hal ini dilaksanakan untuk memperolrh berkah kepada keluarga dan sang bayi. Upacara tersebut dilaksanakan dihadiri oleh

Al Qalam: Jurnal Ilmiah Keagamaan dan Kemasyarakatan Vol. 16, No. 1 Januari - Juni 2022 
Sudarto : Makna Simbolik dan Nilai-Nilai Buddhis Pada Tradisi Pemberian Nama Orang Jawa (Suatu Kajian Semiotik)

masarakat sekitar, saudara dan tetangga yang berada di dekat rumah. Upacara Njengakno tersebut dapat diartikan sebagai kenduri hampir sama pengertianya. Njengakno dilakukan dengan upacatra yang dipimpin oleh pemuka atau tokoh masyarakat yang dituakan (sesepuh). Dalam upacara tersebut terdapat sesajian yang disiapkan diantaranya: 1) Jajan pasar, 2) Bubur Putih/bubur abang (merah) 3) kupat lepet 4) wedhang buthek (Kopi), 5) wedhang bening (air putih), 6) Pisang, 7) Lilin, 8) dupa, 9) kembang (bunga) 10) dekem (ingkung). Setelah sesajian tersebut lengkap dihadapan tamu, sesepuh akan membacakan sebuah doa-doa dan pengharapan, serta menyerahkan sesajian tersebut kepada leluhur (punden) yang berada di Desa Tunahan, serta memohon keberkahan atas kelancaran kelahiran, dan dapat memberikan doa pengharapan baik. Sesajian tersebut merupakan sesajian inti yang harus ada disaat pelaksanaan uoacara tradisi Njengakno dan masing-masing sesajian tersebut memiliki arti yang memberikan berkah kebaikan kepada keluarga dan sang bayi.

Setelah acara selesai tamu yang datang mendapatkan asahan, angsul-angsul (sesuatu yang dibawa pulang dengan isian nasi, lauk pauk dan jajanan). Hal tersebut dimaksudkan bahwa ada permohonan kepada leluhur untuk memberikan sebuah pengayoman, kesehatan, kesejahteraan dan tidak terganggu oleh mara dan bahaya. Demikian adalah proses tradisi Njengakno atau pemberian nama kepada bayi yang baru lahir di desa Tunahan. (observasi acara sepasaran (Njengakno) Bayi Rakhana Naresvara, Putra pertama Bapak Mujiyono dan Ibu wahyu Puspita Sari, Tunahan RT 06 RW 02 tanggal 3 maret 2021)

2. Unsur berdasarkan waktu dalam penyelenggaraan upacara ritual njengakno di Desa Tunahan Kecamatan Keling Kabupaten Jepara

Penyelengaraan upacara dalam upacara tradisi njengakno (pemberian nama orang Jawa) terikat pada peraturan yang disepakati secara bersama dan dapat dilaksanakan pada hari tersebut serta sesuai dengan peraturan adat yang berlaku secara turun temurun. Upacara ini diselenggarakan biasanya lima hari setelah bayi dilahirkan. Maksud dari upacara njengakno tersebut adalah untuk memberi nama pada sang bayi sesuai dengan adat atau kebudayaan yang ada.

Pelaksanaan upacara njengakno atau sepasaran baik dilaksanakan setelah lima hari misalnya anak lahir hari Rabu wage lima hari kedepanya, neptu itu lah dilaksanakan upacara sepasaran menurut kalender jawa. Maksud dan tujuan dari pelaksanaan upacara sepasaran tersebut adalah doa-doa yang di selenggarakan oleh keluarga yang dipimpin oleh sesepuh dan di hadiri oleh masyarakat sekitar untuk memohon sebuah pengharapan yang baik.

Al Qalam: Jurnal Ilmiah Keagamaan dan Kemasyarakatan Vol. 16, No. 1 Januari - Juni 2022 
Sudarto : Makna Simbolik dan Nilai-Nilai Buddhis Pada Tradisi Pemberian Nama Orang Jawa (Suatu Kajian Semiotik)

Berdasarkan data yang diperoleh terkait pelaku dalam acara pemeberian nama atau njengakno tersebut adalah Bapak Mujiyono dan Ibu Wahyu Puspita Sari yang telah di karuniai anak pertamanya di desa Tunahan.

3. Unsur pelaku dalam acara ritual njengakno di Desa Tunahan Kecamatan Keling Kabupaten Jepara

Pelaksanaan dan penyelenggaraan upacara njengakno atau pemberian nama secara teknis, dilaksanakan oleh orang yang dituakan atau sesepuh desa masyarakat desa Tunahan dan di hadiri oleh sanak keluarga dan tetangga.

Sesepuh memiliki peranan penting dalam acara upacara njengakno dikarenakan sesepuh yang mengatasi segala kelancaran, pemandu doa serta memberikan arahan kepada keluarga sang bayi, mengatur sesajian yang ada serta mempersiapkan berlangsungnya acara upacara njengakno.

Berdasarkan wawancara dengan Bapak Raseman adalah Bapak kandung dari Ibu Wahyu Puspita sari mengunkapkan bahwa:

"mbah kariyan sing bakal njangkepke acara njengakno dadi seko kawiwitane bayi lahir samubaeang tekone sesajen mbahe sik ngujubne kanggo kirim donga marang leluhur" (wawancara dengan bapak Raseman, 24 April 2021)

Berdasarkan kutipan hasil wawancara di atas menjelaskan bahwa sesepuhlah yang menjadi sumber acuan dalam menentukan hari, menyiapkan sesajian yang di siapkan dalam acara njengakno. Dengandemikian dapat ditegaskan bahwa sespuh sangat berperan penting dalam acara kelancara upacara tradisi njengakno.

4. Unsur perlengkapan dalam upacara ritual njengakno di Desa Tunahan Kecamatan Keling Kabupaten Jepara

Upacara pemberian nama atau njengakno memiliki beberapa persyaratan yang harus terpenuhi demi kelancaran upacara njengakno. Persyaratan tersebut berupa alat, makanan yang dibagikan dan cara pembuatannya, waktu dan tempat upacara pemberian nama dilaksanakan dan jumlah orang yang akan diundang. Persyaratan tersebut dari masing-masing komponen memiliki makna yang berkaitan dengan pandangan hidup dan keinginan-keinginan yang diharapkan oleh orang tua atau masyarakat sekitarnya terhadap bayi yang baru lahir.

Persyaratan yang harus ada dalam tradisi upacara pemberian nama atau njengakno terdiri dari: 1) Jajan pasar, 2) Bubur Putih/bubur abang (merah) 3) kupat lepet 4) wedhang buthek (Kopi), 5) wedhang bening (air putih), 6) Pisang, 7) Lilin, 8) dupa, 9) kembang (bunga) 10) dekem (ingkung). Ditambah dengan asahan atau bekal yang nanti di bawa pulang oleh tamu yang diundang.

Al Qalam: Jurnal Ilmiah Keagamaan dan Kemasyarakatan Vol. 16, No. 1 Januari - Juni 2022 
Sudarto : Makna Simbolik dan Nilai-Nilai Buddhis Pada Tradisi Pemberian Nama Orang Jawa (Suatu Kajian Semiotik)

Beberapa komponen di atas wajib dan haru ada disaat pelakasanan upacara njengakno dikarenakan itu adalah bagian terpenting dalam tradisi upacara pemeberian nama atau njengakno.

5. Unsur doa dalam upacara tradisi njengakno di Desa Tunahan Kecamatan Keling Kabupaten Jepara

Sesepuh desa Tunahan Bapak Kariyan menjelaskan bahwa doa yang terlantun merupakan doa yang bersifat lisan (verbal) namun di sisi dalamnya memiliki berkah pengharapan yang baik serta memeiliki makna ynag sangat mnedalam. Setiap orang memiliki keyakinan terhadapa Tuhan Yang Maha Esa dengan demikian dengan kondisi baik dan didukung dengan karma lingkungan yang mendukung doa akan terealisasikan dengan sempurna. Dengan memiliki suatu tekat yang besar tentunya doa yang dialunkan memberikan sebuah pencerahan serta kedamaian. Waktu dan tempat memebrikan sebuah kekuatan untuk menyatukan keyakinan serta berpikir positif untuk mengkondisikan .

Dalam khasanah spiritual jawa disebutjan "bisa nggayuh kawicaksanane Gusti” . Agar doa menjadi kuat dapat dilakukan dengan kiat tertentu. Sangat penting untuk dipahami bahwa doa tidak hanya sekedar permohonan yang bersifat verbal, melainkan doa adalah sebuah usaha yang nyata. Permohoanan doa kepada Tuhan tentunya diimbangi dengan penggabungan antara batiniah dan lahiriah.

Doa merupakan kalimat sederhana dan merupakan kata kunci dari kekuartan doa adalah tercermin dari amal kebaikan yang pernah dilakukan kepada sesama.

Upacara tradisi yang saat ini masih berlaku di masyarakat Jawa adalah terdapat doa di setiap upacara-upacara. Demikian juga berkenaan dengan upacara tradisi pemberian nama atau njengakno di desa Tunahan Kecamatan Keling Kabupaten Jepara, terdapat doa-doa yang sangat sakral dan penting di dalam upacara pemberian nama atau njengakno. Doamenjadi sebuah unsur yang sangat penting dalam tradisi njengakno, doa tersebut ditujukan kepada Tuhan Yang Maha Esa dan para leluhur atau nenek moyang untuk memperoleh pengharapan baik, keselamatan, kesehatan dan karma baik dalam hidup. Doa selalu mengiringi dalam acara upacara-upacara tradisi.

Penempatan among (cok bakal) terdapat doa-doa yang dilantunkan sebagai bentuk permohonan dan pertolongan kepada leluhur atau pamomong dari sang bayi supaya selalu menjaga dan melindungi dari sengkala atau mara bahaya. Contohnya:

Kutipan :

Kyai among nyai among, ngaturaken pisungsung kagem para leluhur ingkang sami nurunaken jabang bayine.... (diisi nama anak) mugio tansah kersa njangkung lan njampangi lampahipun, dados lare utowo tiyang ingkang tansah hambeg utama, wilujeng rahayu, mulya,

Al Qalam: Jurnal Ilmiah Keagamaan dan Kemasyarakatan Vol. 16, No. 1

Januari - Juni 2022 
Sudarto : Makna Simbolik dan Nilai-Nilai Buddhis Pada Tradisi Pemberian Nama Orang Jawa (Suatu Kajian Semiotik)

sentosa lan raharja. Wilujeng rahayu kang tinemu, bondo lan bejo kang teko. Kabeh saka kersaning Gust Ingkang Moho Agung.

Terjemahan :

"Para pengasuh lahir dan batinku (kakang kawah adi ari-ari, sedulur papat keblat dan kelima pancer), dan seluruh leluhur pendahulu si jabang bayi ... (sebutkan nama anak), ijinkan saya menghaturkan segala uborampe bancakan weton sebagai wujud rasa menghargai, rasa hormat, dan terimakasih. Semoga selalu bersedia untuk membimbing dan mengarahkan dalam setiap langkah. Agar menjadi orang yang berifat mulia, luhur budi pekerti, bermanfaat untuk seluruh makhluk. Selalu mendapat keselamatan kebahagiaan dan kesentosaan, dan selalu mendapakan keberuntungan kapan dan di manapun berada."

Doa yang dilntunkan bisa secara lisan, dalam upacara pemberian nama atau njengakno. Pada saat sebelum acara dimulai dengan menyulut hio atau dupa tentunya pembacaan parrita oleh sesepuh telah dilaksanakan dengan tujuan kelancaran dalam upacara njengakno serta sebelum acara dimulai doa dilantunkan oleh sespuh guna mendukung acara. Doa yang ditujukan kepad Tuhan Yang Maha Esa serta para leluhur selalu mengiringi saat prosesi upacara njengakno berlangsung dengan tujuan diberikan keselamatan dan umur panjang serta di jauhkan dari mara bahaya atau sengkala dan anak menjadi tumbuh besar, menjadi anak yang berguna bagi orang tua, keluarga , masyarakat dan bangsa untuk si bayi itu sendiri.

Berbagai unsur di atas yang sudah dijelaskan merupakan sebuah unsur yang dapat membangun terciptanya upacara njengakno. Unsur tersebut adalah daya topang yang paling kuat dari satu kesatuan dalam upacara pemeberian nama atau njengakno di Desa Tunahan Kecamatan Keling Kabupaten Jepara. Tanpa adanya unsur-unsur yang saling berkaitan tersebut di atas pelaksanaan upacara pemberian nama njengakno tidak akan terlaksana dengan baik dan lancar .

\section{Makna Simbolik yang terkandung di dalam tradisi ritual Njengakno di Desa Tunahan}

Penjelasan berkaitan dengan makna simbolik yang terdapat pada unsur-unsur pendukung tadisi pemberian nama orang atau njengakno dii Desa Tunahan berdasarkan konsep semiotika Charles Sanders Peirce. Charles berasumsi bahwa sebuah benda mempunyai tiga elemen utama yaitu tanda, objek dan interpretan (dalam Sobur 2006). Berdasarkan makna dari tradisi upacara pemberian nama atau njengakno merupakan sebuah "objek" dijelaskan menurut konsep semiotika bahwa ada tiga hal yang masuk dalam konsep tersebut diantaranya, ikon, indeks dan simbol. Ikon merupakan tanda yang dicirikan oleh persamaan dengan objek yang digambarkan. Berbeda dengan indeks yang mempunyai hubungan secara langsung antara tanda dan objek yang keduanya dihubungkan. Memiliki hubungan yang sangat erat eksistensialnya langsung dengan objeknya.

Al Qalam: Jurnal Ilmiah Keagamaan dan Kemasyarakatan Vol. 16, No. 1

Januari - Juni 2022 
Sudarto : Makna Simbolik dan Nilai-Nilai Buddhis Pada Tradisi Pemberian Nama Orang Jawa (Suatu Kajian Semiotik)

Simbol merupakan sebuah tanda yang memiliki hubungan langsung dengan obkejnya berdasarkan konvensi, kesepakatan atau aturan.

Berdasarkan penjelasan di atas berkenaan dengan analisis semiotika peneliti menjelaskan berkaitan dengan makna simbolik berkaitan dengan upacara tradisi njengakno. Peneliti memfokuskan pada makna simbolik sebagai mana ada di dalam upacara njengakno di Desa Tunahan Kecamatan Keling Kabupaten Jepara.

1. Analisis Makna Simbolik dalam tradisi njengakno di Desa Tunahan

Suatu tanda atau simbol merupakan suatu stimulus yang menandai kehadiran sesuatu yang lain. Dengan demikian suatu tanda berhubungan erat dengan maksudtidakan yang sebenarnya (Morrisan, 2013:89). Dapat diartikan bahwa sebuah simbol merupakan konvensi bersama atau kesepakatan dari masyarakat. Sebagai contoh tanda stop dengan ada tanda merah bergaris silang, merupakan suatu larangan untuk berhenti berkendara di jalan dengan ada tanda tersebut.

Berdasarkan Concise Oxford Dictionary, menjelaskan bahwa simbol adalah suatu hal yang disepakati banyak orang memiliki sifat atau ciri-ciri analogis yang sesuai dengan fakta atau ide atau pikiran. Secara empiris symbol-simbol yang diamati adalah benda, aktivitas, hubungan, kejadian, isyarat dan kelompok spasial dalam situasi ritual. Symbol ritual disini menjadi suatu faktor dalam aksi sosial kekuatan positif dalam bidang aktivitas.

Upacara atau ritual merupakan sebuah simbol yang memiliki makna dan fungsinya sebagai norma yang ada di dalam masyarakat dengan mengembalikan sebuah penyimpangan yang dilakukan oleh lingkunganya atau masyarakatnya melalui sanksi atau teguran yang akan diberikan.

2. Simbol dominan pa Sesajen tradisi njengakno di Desa Tunahan

Perlengkapan sesajian yang disiapkan dalam acara upacara pemberian nama atau njengakno dapat diasumsikan bahwa dalam upacara njengakno tersebut mengandung simbol dominan yang berupa sesajian diantaranya: 1) Jajan pasar, 2) Bubur Putih/bubur abang (merah) 3) kupat lepet 4) wedhang buthek (Kopi), 5) wedhang bening (air putih), 6) Pisang, 7) Lilin, 8) dupa, 9) kembang (bunga) 10) dekem (ingkung). Berdasarkan sesepuh unsur-unsur yang terdapat dalam sesaji ini dikatakan sebagai simbol dominan karena terdapat pada semua upacara atau ritual dikalangan masyarakat Jawa.

Dilihat dari literasi antar makna dan simbol dari simbol yang bersifat dominan, dapat dipahami bahwa unsur dominan yang pasti ada di setiap upacara pada masyarakat Jawa yaitu tradisi sepasaran bayi atau pemberian nama (njengakno) sebagai awal penamaan bayi adalah usaha sadar untuk memebrikan pemahaman bahwa hakikat manusia dijadikan oleh Tuhan dari unsur laki-laki dan perempuan, ketika diandung oleh ibu dalam rahim selama sembilan bulan

Al Qalam: Jurnal Ilmiah Keagamaan dan Kemasyarakatan Vol. 16, No. 1 Januari - Juni 2022 
Sudarto : Makna Simbolik dan Nilai-Nilai Buddhis Pada Tradisi Pemberian Nama Orang Jawa (Suatu Kajian Semiotik)

sepuluh hari, bayi dilindungi oleh unsur lain seperti kawah (air ketuban), sehingga dengan keberadaan kedua unsur tersebut bayi akan aman dari berbagai gangguan atau guncanganyang dialami oleh seorang ibu yang mengandungnya.

Berdasarkan hal tersebut masnusia diingatkan untuk tetap menjadi manusia yang selalu berbuat baik, berperilaku baik, menghindarkan diri dari kejahatan dan mendekatkan diri dengan Tuhan Yang Maha Kuasa. Dengan demikian manusia akan terarah dan tercapai kebahagianya.

Masyarakat di Desa Tunahan melaksanakan upacara pemberian nama atau njengakno merupakan sesuatu tradisi yang tidak meninggalkan dengan anya pemaknaan sebuah simbol yang sudah disepakati secara bersama. Sesaji dalam acara upacara njengakno memiliki banyak simbolsimbol yang terkandung didalamnya. Simbol-simbol tersebut terkandung pada sesajian yang dihidangkan dalam upacara njengakno. Makna simbolik dari sesaji tersebut adalah:

a) Jajan pasar,

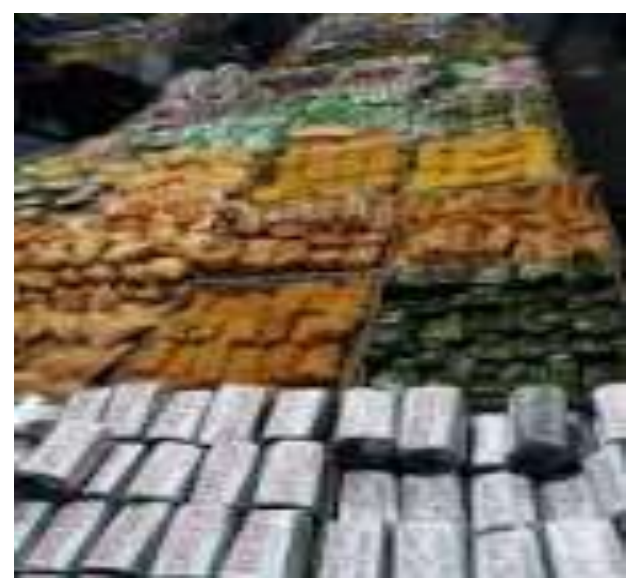

(sumber: Peneliti)

Jajan pasar terdiri dari makanan tradisional yang dibeli dari pasar diantaranya wajik, jadah, lemper dan lain-lain. Makna simbolik dari jajan pasar adalah rejeki, kesehatan, keselamatan supaya selalu meneyertai kemanapun kita pergi dan dimanaoun kita berada. (sumber wawancara dari Bapak Kariyan (sesepuh))

b) Bubur putih, Bubur Abang

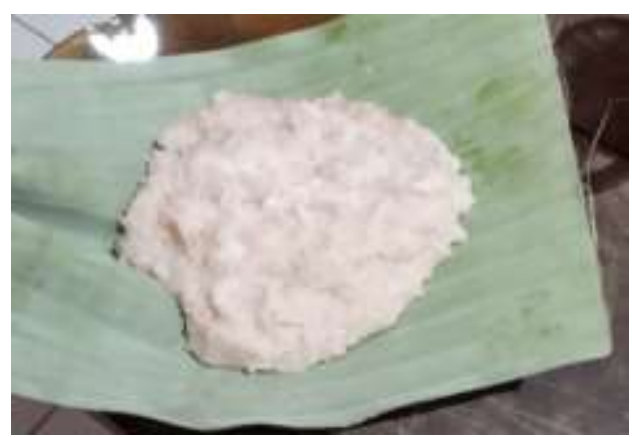

Sumber : Peneliti

Al Qalam: Jurnal Ilmiah Keagamaan dan Kemasyarakatan Vol. 16, No. 1 Januari - Juni 2022 
Sudarto : Makna Simbolik dan Nilai-Nilai Buddhis Pada Tradisi Pemberian Nama Orang Jawa (Suatu Kajian Semiotik)

Makna dari simbol bubur putih dan bubur abang tersebut adalah bubur merah merupakan lambang ibu. Bubur putih adalah lambang ayah. Lalu terjadi hubungan silang menyilang, timbal-balik, dan ditandai sebagai kelahiran seorang anak. Hal ini menyiratkan ilmu sangkan, asal mula kita. Menjadi pepeling (pengingat)agar jangan sampai kita menghianati orang tua, menjadi anak yang durhaka kepada orangtua. (sumber wawancara dari Bapak Kariyan (sesepuh))

c) Kupat lepet

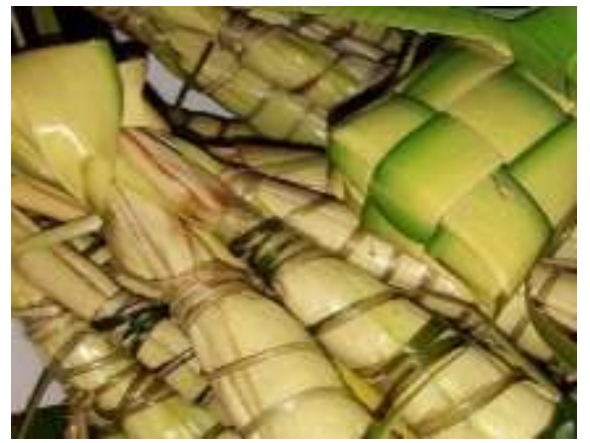

Sumber: Peneliti

Makna simbolik dari kupat dan lepet adalah filosofi kita sebagai manusia hendaknya selalu mengakui kesalahan (Lepat) jika kita melakukan kesalahan yang disengaja ataupun tidak disengaja. Sedangkan lepet memberikan pengertian dalam bahasa jawa yaitu "silep ingkang rapet” (menutup yang rapat) setelah kita mengakui kesalahan menutup kesalahan yang sudah dimaafkan. (sumber wawancara dari Bapak Kariyan (sesepuh))

d) Wedhang buthek (Kopi) dan Wedhang bening (air putih)
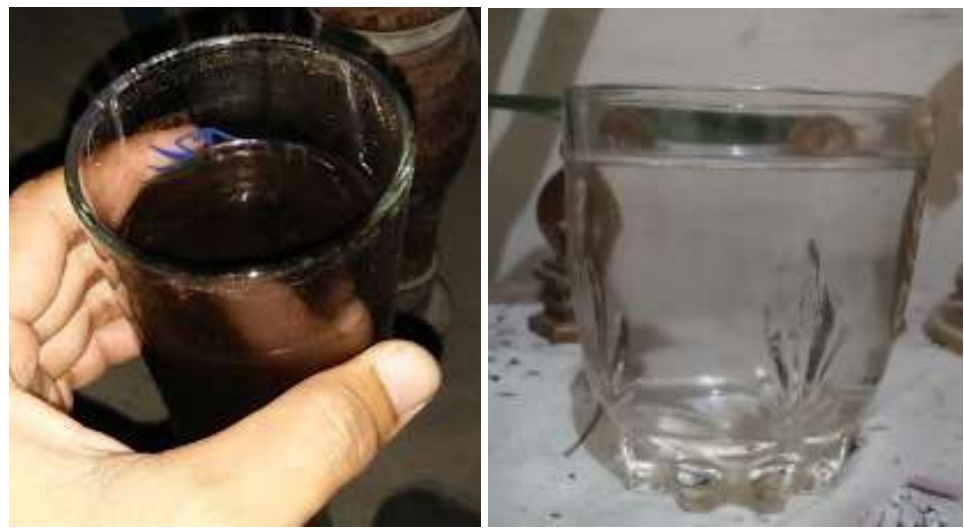

Wedhang Kopi Wedhang putih

Sumber: Peneliti

Makna simbolik dari wedhang buthek (kopi) dan Wedhang bening (air putih) adalah elemen air merupakan salah satu kebutuhan pokok manusia dan menjadi lambang sebuah persaudaraan bila ada perkumpulan atau pertemuan. (sumber wawancara dari Bapak Kariyan (sesepuh))

e) Pisang,

Al Qalam: Jurnal Ilmiah Keagamaan dan Kemasyarakatan Vol. 16, No. 1 Januari - Juni 2022 
Sudarto : Makna Simbolik dan Nilai-Nilai Buddhis Pada Tradisi Pemberian Nama Orang Jawa (Suatu Kajian Semiotik)

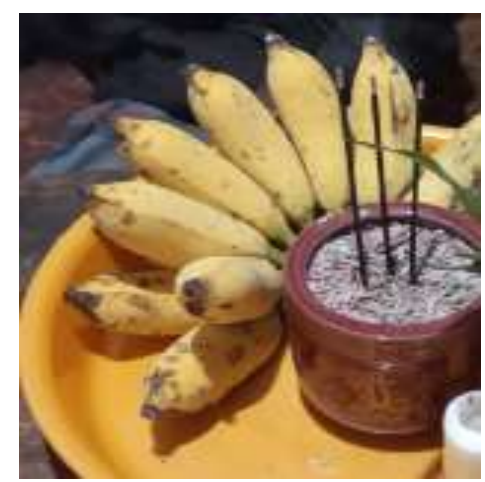

Sumber: Peneliti

Makna simbolik dari sesajian pisang adalah meberikan makna bahwa seluruh yang menjaga (pamomong) agar menjaga dan menopang kehidupan atau kehidupan kedepanya menjadi bermanfaat dan berdaya guna untuk menjaga kehidupan (hamemayu hayuning bawana). (sumber wawancara dari Bapak Kariyan (sesepuh))

f) Lilin,

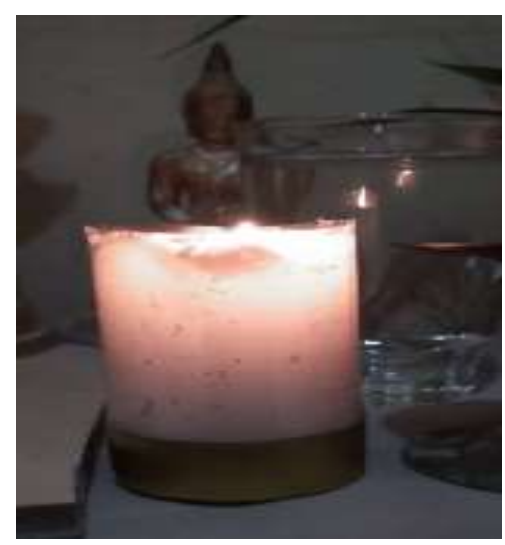

Sumber: Peneliti

Makna simbolik dari lilin adalah diartikan sebagai penerang dalam kegelapan, dimana seseorang bisa menjadikan sebagai penerang dalam sebuah kehidupan dan menjadi suritauladan dalam bersikap. (sumber wawancara dari Bapak Kariyan (sesepuh))

g) Dupa,

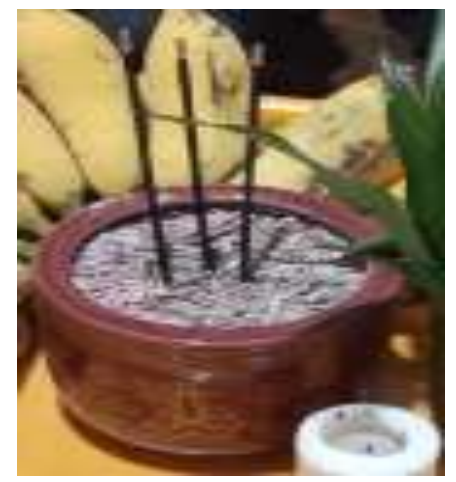

Sumber: Peneliti

Al Qalam: Jurnal Ilmiah Keagamaan dan Kemasyarakatan Vol. 16, No. 1 Januari - Juni 2022 
Sudarto : Makna Simbolik dan Nilai-Nilai Buddhis Pada Tradisi Pemberian Nama Orang Jawa (Suatu Kajian Semiotik)

Makna simbolik dari dupa merupakan sebuah makna yang perlu di terapkan dan dipedomani bahwa manusia bisa memberikan sebuah keharuman, penyejuk serta pemberi nasihat yang baik. Serta meberikan keharuman dhamma (ajaran) kepada seluruh umat manusia. (sumber wawancara dari Bapak Kariyan (sesepuh))

h) Kembang (bunga)

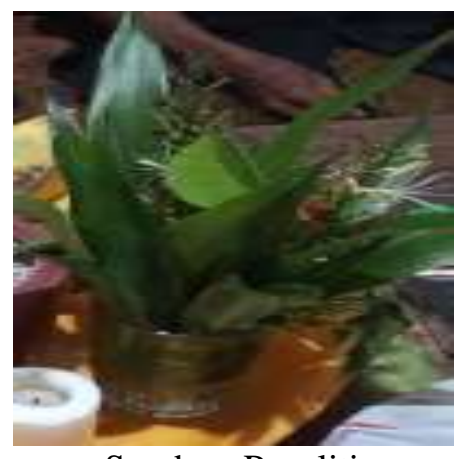

Sumber: Peneliti

Kembang disajikan dalam wadah yang berisi air. Makna simbolik dari kembang adalah nama dan keluarga sang bayi tetap harum di dalam kehidupan masyarakat, selayaknya bunga yang ada pada kembang di dalam wadah berisi air tersebut, bila dari jauh bau dari bunga yersebut masih terasa (sumber wawancara dari Bapak Kariyan (sesepuh))

i) Dekem(ingkung).

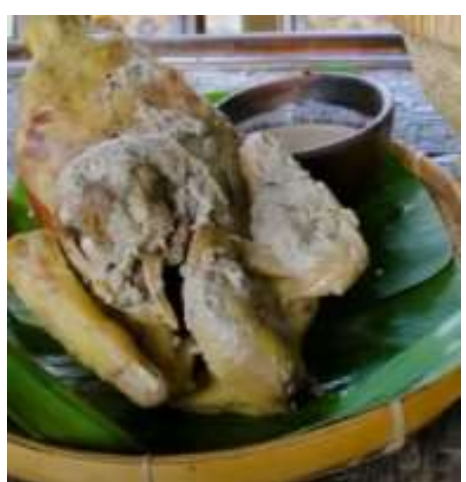

Sumber: Peneliti

Ingkung atau dekem adalah ayam yang dimasak dengan menggunakan santan. Dari ingkung memiliki makna simbolik bayi yang masih bersih dan suci serta belum memiliki kesalahan sekecil apapun. Ingkung dimaknai sebagai sikap pasrah dan menyerah atas kekuasaan Tuhan Yang Maha Esa. Orang Jawa mengartikan kata ingkung di banda (tali) sebagai bentuk belenggu. Pengartian makna ingkung tersebut meberikan artian bahwa untuk mensucikan keluarga atau irang yang memiliki hajat (gawe) atau para tamu undangan yang datang pada acara selametan, dalam hal ini acara pemberian nama orang atau njengakno di Desa Tunahan Kecamatan Keling Kabupaten Jepara. (sumber wawancara dari Bapak Kariyan (sesepuh))

Al Qalam: Jurnal Ilmiah Keagamaan dan Kemasyarakatan Vol. 16, No. 1 Januari - Juni 2022 
Sudarto : Makna Simbolik dan Nilai-Nilai Buddhis Pada Tradisi Pemberian Nama Orang Jawa (Suatu Kajian Semiotik)

\section{Nilai-Nilai Buddhis Yang Terkandung Di Dalam Tradisi Ritual Njengakno Di Desa Tunahan}

Tradisi merupakan pelaksanaan upacara yang bersifat sakral dan penting. Upacara merupakan warisan dari nenek moyang yang tetap dilesatikan hingga saat ini. Agama Buddha sendiri memiliki cara untuk melaksanakan penghormatan kepada Buddha dengan menggunakan altar sebagai penunjang dalam melaksanakan penghormatan. Hal ini dilaksanakan berkaitan dengan upacara tradisi sudah diwariskan kepada anak cucu sehingga tetap dilaksanakan hingga saat ini.

Widiyanto (2021:58) menjelaskan berkaitan dengan tradisi dalam agama Buddha menerangkan bahwa dalam memanggil Dewa (Devata Aradhana) dalam tradisi Tionghoa adalah untuk meberi penghormatan, sekaligus menunjukkan rasa bakti kepada para dewa atas perlindungan dan bimbingannya. Tetapi dalam tradisi Buddha adalah mengajak para Dewa turut serta dalam mendengarkan dan merenungkan kembali Dhamma Buddha lewat Pembacaan Paritta. "Semoga para dewa di segenap alam datang, kesini mendengarkan Ajaran Kebenaran Buddha, Raja para bijaksana, yang membimbing ke surga dan kebebasan. Datanglah para dewa yang bersemayam di surga, yang berada ditingkat alam napsu ataupun di tingkat alam berbentuk; juga dewa bumi yang bersemayam di vimana (tempat menyenangkan/bersemayam para dewa) atau di puncak gunung, di jurang, di angkasa, di pulau, di kota, di desa, di pepohonan, di hutan belukar, di sekitar rumah atau di sawahsawah dan ladang; juga para yakkha, gandhabba, dan naga yang bersemyam di perairan, daratan atau pun di perbukitan. Silahkan mereka yang berada disekitar ini mendengarkan sabda Buddha, Raja para bijaksana, seperti beikut ini. Sekarang tiba saatnya mendengarkan Dhamma (3X).

Jadi tradisi puja adalah untuk melatih kualitas batin seseorang bukan untuk meminta berkah. Puja dapat berupa materi (amise puja) seperti persembahan Lilin, Hio/dupa, Air, Bunga, Buah-buahan dan makanan. Dapat juga berupa perbuatan/ prilaku ( pati-pati puja). Berdasarkan pengertian di atas dapat dijelaskan bahwa tradisi untuk melaksanakan pemujaan dapat dilaksanakan dengan memberikan persembahan-persembahan dengan harapan mendapatkan kondisi baik.

Penjelasan di atas dapat digaris bawahi bahwa tradisi Njengakno hampir beriringan sesuai dengan tradisi pemujaan dalam konsep Agama Buddha, serta memiliki beberapa nilai-nilai yang terkiandung di dalamnya berkaitan dengan sarana puja yang dihaturkan. Pada dasarnya persembahan yang diberikan dan di sajikan dalam upacara tradisi pemberian nama ada kemiripan dalam penyajian yang dipersembahkan meliputi lilin, bunga, dupa air dan buah-buahan.

Al Qalam: Jurnal Ilmiah Keagamaan dan Kemasyarakatan Vol. 16, No. 1 Januari - Juni 2022 
Sudarto : Makna Simbolik dan Nilai-Nilai Buddhis Pada Tradisi Pemberian Nama Orang Jawa (Suatu Kajian Semiotik)

Penjelasan berkaitan dengan sarana puja yang di persembahkan kepada leluhur dijelaskan oleh Sang Buddha dalam Khuddaka Nikāya: Khuddaka Pāṭ ha, Tirokudda Sutta, sebagai berikut: "So they who are compassionate. At heart do give for relatives. Such drink and food as may be pure and good and fitting at these times. As water showered on the hill. Flows down to reach the hollow vale. So giving given here can serve. The ghosta of the departed kin. As riverbeds when full can bear. The water down to fill the sea. So giving geven here can serve. The ghosts of the departed kin. He gave to me, he worked for me. He was my kin, friend, intimate. Give gifts, then, for departed ones. Recalling what they used to do. But when this offering is given. Well placed in the Community. For them, then it can serve them long. In future and at once as well ${ }^{22}$ (Ñān amoli, 2005: p. 231-239)." (Suhartoyo, dkk: 2014: 36).

Berdasarkan kutipan di atas memiliki pengertian bahwa para penyokong memberikan minuman dan makanan yang bersih, lembut dan sesuai dengan waktunya dengan bertekad demikian; 'semoga pemberian ini melimpah kepada sanak keluarga yang telah meninggal. Semoga mereka berbahagia. Sebagaimana air hujan yang turun di dataran tinggi mengalir ke tempat rendah; demikian persembahan yang disampaikan oleh sanak keluarga dari alam manusia akan menuju ke para mendiang. Sebagaimana sungai yang meluap airnya akan mengalir memenuhi lautan;' demikianlah persembahan yang disampaikan oleh sanak keluarga dari alam manusia akan menuju ke para mendiang. Orang yang mengenang budi yang mereka lakukan di waktu lampau bahwa, Ia memberi ini kepadaku. Ia melakukan hal ini untukku. Ia adalah kerabatku, sahabatku, dan temanku, patut memberikan persembahan dāna kepada mereka yang telah meninggal. Persembahan yang telah dihaturkan ini, yang disajikan dengan baik kepada Sangha, akan segera bermanfaat bagi mendiang itu sepanjang waktu yang lama. Sang Buddha menganjurkan cara yang lebih bijaksana bagi sanak keluarga yang telah meninggal, yaitu dengan berdana makanan, minuman serta lain-lain kepada para Bhikkhu Sangha dan selanjutnya menyalurkan jasa kebajikan yang timbul dari pemberian dana ini kepada leluhur.

Dengan demikian dapat diperjelas bahwa sarana puja atau sesajian yang diberikan dalam upacara njengakno seperti halnya 1) Jajan pasar, 2) Bubur Putih/bubur abang (merah) 3) kupat lepet 4) wedhang buthek (Kopi), 5) wedhang bening (air putih), 6) Pisang, 7) Lilin, 8) dupa, 9) kembang (bunga) 10) dekem (ingkung), merupakan penyaluran doa kepada diri pribadi sehingga diberikan kesehatan, umur pannjang, kemulyaan serta kesejahteraan selain itu juga ditujukan kepada para leluhur dengan mempersembahkan sarana puja yang sajikan. Untuk memperoleh

\footnotetext{
${ }^{22}$ Ñāṇ amoli 2005. The Minor Readings (Khuddakatāt tha). Oxford: The Pali Text Society. Hlm $231-239$
}

Al Qalam: Jurnal Ilmiah Keagamaan dan Kemasyarakatan Vol. 16, No. 1 Januari - Juni 2022 
Sudarto : Makna Simbolik dan Nilai-Nilai Buddhis Pada Tradisi Pemberian Nama Orang Jawa (Suatu Kajian Semiotik)

berkah kebaikan kepada sanak keluarga yang sudah meninggal agar mencapai kebahagian sempurna atau Nibbana.

Nilai-nilai Buddhis dalam tadisi upacara njengakno dapat diartikan memberikan dampak yang positif, disisi lain sebagai bentuk bakti kita kepada leluhur serta menjaga tradisi yang sudah diwariskan serta meberikan berkah kebaikan bagi makhluk yang tidak terlihat. Persembahan dalam upacara njengakno memberikan berbagai suri tauladan bahwa kita sebagai umat manusia untuk menjaga serta mewariskan tradisi kepada anak cucu. Tradisi tersebut merupakan kebudayaan yang dapat dijadikan sebagai tonggak sejarah dalam artian memberikan pengaharapan baik, kesehatan, keselamatan dan bakti kita kepada sang pencipta sehingga kita senantiasa selalu di dalam dingungannya yaitu Buddha, Dhamma dan Sangha.

\section{KESIMPULAN}

Berdasarkan hasil penelitian dan pembahasan yang telah dilaksanakan terhadap Makna Simbolik Dan Nilai-Nilai Buddhis Pada Tradisi Pemberian Nama Orang Jawa Di Desa Tunahan Kecamatan Keling Kabupaten Jepara diperoleh kesimpulan sebagai berikut:

1. Tradisi ritual Njengakno di Desa Tunahan Kecamatan Keling Kabupaten Jepara dilaksanakan setelah sang bayi sudah sepasar dan upacara njegakno dilangsungkan, upacara njengakno merupakan tradisi yang turun temurun dengan adanya upacara tersebut masyarakat meyakini bahwa sang bayi akan mendapatkan keselamatan kesehatan dan kesejahteraan serta dijaukan dari marabahaya. Tardisi njegakno yang dilaksanakan di desa Tunahan tersebut di laksanakan dengan adanya persembahan yang ada dalam komponen sesaji diharapkan dengan sesajian yang dihidangkan untuk leluhur dapat memberikan sesuatu yang positif bagi sang bayi.

2. Makna simbolik yang terkandung di dalam tradisi ritual Njengakno di Desa Tunahan Kecamatan Keling Kabupaten Jepara, merupakan makna dari masing masing sesajian yang dipersembahkan dalam upacara njegakno sesajian tersebut adalah: a) Jajan pasar dengan memiliki Makna rejeki, kesehatan, keselamatan supaya selalu meneyertai kemanapun kita pergi dan dimanaoun kita berada, b) bubur putih dan bubur abang memiliki makna ditandai sebagai kelahiran seorang anak, c) Kupat lepet makna simboliknya adalah filosofi kita sebagai manusia hendaknya selalu mengakui kesalahan (Lepat) jika kita melakukan kesalahan yang disengaja ataupun tidak disengaja. Sedangkan lepet memberikan pengertian dalam bahasa jawa yaitu "silep ingkang rapet" (menutup yang rapat) setelah kita mengakui kesalahan menutup kesalahan yang sudah dimaafkan, d) Wedhang buthek (Kopi) dan Wedhang bening (air putih) Makna simboliknya adalah elemen air merupakan salah satu kebutuhan pokok manusia dan menjadi lambang sebuah persaudaraan bila ada perkumpulan atau pertemuan, e) Pisang memiliki Makna simbolik

Al Qalam: Jurnal Ilmiah Keagamaan dan Kemasyarakatan Vol. 16, No. 1

Januari - Juni 2022 
Sudarto : Makna Simbolik dan Nilai-Nilai Buddhis Pada Tradisi Pemberian Nama Orang Jawa (Suatu Kajian Semiotik)

memberikan makna bahwa seluruh yang menjaga (pamomong) agar menjaga dan menopang kehidupan atau kehidupan kedepanya menjadi bermanfaat dan berdaya guna untuk menjaga kehidupan (hamemayu hayuning bawana), f) Lilin, Makna simboliknya sebagai penerang dalam kegelapan, dimana seseorang bisa menjadikan sebagai penerang dalam sebuah kehidupan dan menjadi suritauladan dalam bersikap, g) Dupa, Makna simbolik manusia bisa memberikan sebuah keharuman, penyejuk serta pemberi nasihat yang baik. Serta meberikan keharuman dhamma (ajaran) kepada seluruh umat manusia., h) Kembang (bunga) Makna simbolik dari kembang adalah nama dan keluarga sang bayi tetap harum di dalam kehidupan masyarakat, , i) Dekem(ingkung) makna simboliknya bayi yang masih bersih dan suci serta belum memiliki kesalahan sekecil apapun. Ingkung dimaknai sebagai sikap pasrah dan menyerah atas kekuasaan Tuhan Yang Maha Esa.

3. Nilai-nilai Buddhis yang terkandung di dalam tradisi ritual Njengakno di Desa Tunahan Kecamatan Keling Kabupaten Jepara menjelaskan bahwa Nilai-nilai Buddhis dalam tadisi upacara njengaknodapat diartikan memberikan dampak yang positif, disisi lain sebagai bentuk bakti kita kepada leluhur sesuai dengan Parrita Tirokuda sutta serta menjaga tradisi yang sudah diwariskan serta meberikan berkah kebaikan bagi makhluk yang tidak terlihat. Persembahan dalam upacara njengakno memberikan berbagai suri tauladan bahwa kita sebagai umat manusia untuk menjaga serta mewariskan tradisi kepada anak cucu.

\section{DAFTAR PUSTAKA}

2007. Madzhab-Madzhab Antropologi. Yogyakarta: Pelangi Aksara.

2013. Semiotika Komunikasi, Bandung : PT. Remaja Rosdakarya

Alex Sobur.2004. Analisis Teks Media. Bandung: PT Remaja Rosdakarya

Alfian Rokhmansyah.2014. Studi Dan Pengkajian Sastra. Yogyakarta: Graha Ilmu

Ali Imron dan Farida .2017. Pengkajian Sastra Teori dan Aplikasi. Surakarta: CV. Djiva Amarta Pers

Dewa I, P.W \& Rohmadi, M. 2008. Semantik Teori dan Anlisis. Surakarta: Yuma Pustaka.

Dhammananda, Sri.(2002), Keyakinan Umat Buddha. Jakarta: Yayasan Penerbit Karaniya.

H. B. Sutopo 2002.. Metode Penelitian Kualitatif. Surakarta: UNS Press.

Hammis Syafaq. 2012. Pengantar Studi Agama. Surabaya: IAIN Sunan Ampel Press.

Husaini Usman dan Purnomo Setiadi Akbar. 2009. Metodologi Penelitian Sosial. Jakarta: PT Bumi Aksara

Jalaludin, Rakhmat. (1994). Psikologi Komunikasi. Bandung: Remaja Rosdakarya.

Journal Makna Simbol Tradisi JhêّNg Mantoh (Analisa Semiotika Charles Sanders Peirce Vol 13, No 1 (2019) EISSN:2579-8146

Al Qalam: Jurnal Ilmiah Keagamaan dan Kemasyarakatan Vol. 16, No. 1

Januari - Juni 2022 
Sudarto : Makna Simbolik dan Nilai-Nilai Buddhis Pada Tradisi Pemberian Nama Orang Jawa (Suatu Kajian Semiotik)

Journal UnramSemiotics Analysis On The Symbol Of Nyorong Ceremony In Samawa Traditional Marriage

Jurnal Semiotika No. 17, Vol. 6, Desember 2020 / ISSN 1979-3724

Kuncoroningrat. 1954. Sejarah Kebudayaan Indonesia. Yogyakarta: Jambatan

Kusuma, G. ., Yonata, H. ., \& Handoko, A. L. . (2020). Peranan Kebudayaan Tionghoa terhadap Perkembangan Agama Buddha: Studi Kasus di Desa Rancaiyuh Kecamatan Panongan Kabupaten Tangerang. Jurnal Ilmu Agama Dan Pendidikan Agama Buddha, 2(2), 117130. Retrieved from https://journalstabdharmawidya.ac.id/ind ex.php/contents/article/view/19

Lexy. J. Moleong. 2000. Metodologi Penelitian Kualitatif. Bandung: PT Remaja Rosdakarya

Muhaimin AG.2001. Islam Dalam Bingkai Budaya Lokal: Potret Dari Cerebon, Terj. Suganda, Ciputat: Logos Wacana Ilmu

Ñāṇ amoli 2005. The Minor Readings (Khuddakatāt tha). Oxford: The Pali Text Society.

Nur Syam. 2005. Islam pesisir,.Yogjakarta: Lkis Pelangi Aksara,

Panjika. 2004. Kamus Umum Buddha Dharma. Jakarta: Tri Sattva Buddhist Centre.

Pawito. 2007.Penelitian Komunikasi Kualitatif. Yogyakarta: PT LkiS Pelangi Aksara Yogyakarta.

Poerwadarminta, W.J.S. 1976. Kamus Umum Bahasa Indonesia. Jakarta: Balai Pustaka.

Santoso, Joko. 2006. Semantik. Yogyakarta: FBS UNY

Saptono. 2011. Dimensi-dimensi Pendidikan Karakter, Yogyakarta: Erlangga

Sudarto. 1997. Metodologi Penelitian Filsafat. Jakarta: Raja Grafindo Persada

Sudarwan Danim. 2002. Menjadi Peneliti Kualitatif Rancangan Metodologi, Presentasi, dan Publikasi Hasil Penelitian untuk Mahasiswa dan Penelitian Pemula Bidang Ilmu Sosial, Pendidikan, dan Humaniora. Bandung: Remaja Rosdakarya

Sugiyono. 2006. Metode Penelitian Pendidikan; Pendekatan Kuantitatif dan Kualitatif dan R\&D Bandung: Alfabeta

Suharsimi Arikunto.2002. Prosedur Penelitian Suatu Pendekatan Praktek. Jakarta : PT. Rineka Cipta

Suhartoyo, dkk 2014. The Correlation Study On The Merits Transfer Ceremony (Pattidana) With Children's Devotion To The Ancestors In The Kebumen District Of Central Java Jurnal Agama Buddha dan Ilmu Pengetahuan Vol 1, No 1, September 2014 :

Sumandiyo.2007. Sosiologi Budaya, Yogyakarta: Pustaka

Welly, Septiyana. 2020, Tradisi Imlek dan Perubahannya pada Masyarakat Tionghoa Vihara Dharma Agung Tanggamus Lampung. Lam

Widiyanto (2021) Perspektif Agama Buddha Terhadap Berbagai Macam Upacara Tradisi Masyarakat Tionghoa Jurnal Agama Buddha dan Ilmu Pengetahuan Vol. 4, No 1, Juli 2021: 55-61

Al Qalam: Jurnal Ilmiah Keagamaan dan Kemasyarakatan Vol. 16, No. 1

Januari - Juni 2022 